\title{
Ultrastructural Evidences for Endothelial Cell - Leukocytes Interactions: Margination and Migration
}

\author{
Evidencias Ultraestructurales de las Interacciones Células \\ Endoteliales - Leucocitos: Marginación y Migración
}

Engin Deveci \& Ienay Deveci

DEVECI, E \& DEVECI, I. Ultrastructural evidences for endothelial cell-leukocytes interactions: margination and migration. Int. J. Morphol., 28(3):895-898, 2010.

SUMMARY: Leukocyte-endothelial cell interactions have a pivotal role in immune responses. In our study Ten adult wistar albino rats weighing 180-200 g were used to obtain tissue samples. The animals were sacrificed by decapitation under ether anesthesia. The lymph nodes of the animals were then quickly removed. Specimens were immersed in the zinc iodide-osmium tetroxide (ZIO) solutation by Niebauer et al. (1969) and kept in the dark for 2 hours in this solution from temperature for fixation/staining. Samples were processed according to routine plastic embedding tecnique. Semithin sections of $1 \mu \mathrm{m}$ thick were cut and stained with methilene blueazure II for light microscopic examination. We used zinc iodide-osmium tetroxide staining tecnique to distinguish endothelial cell from leukocytes.Present data supports the understanding of this unique relationship as documented by figures.

KEY WORDS: Leukocytes; Margination; Migration.

\section{INTRODUCTION}

Leukocyte adhesion to vascular endothelium is an initial and rate-limiting step in the cascade of events that lead to inflamation. Two important determinants of the leukocyte-endothelial cell adhesion observed during inflamation are shear forces generated by the movement of blood within the microcirculation and adhesion glycoproteins expressed on the surface of leukocytes and endothelial cell (Granger \& Kubes, 1994; Farr \& De Bruyn, 1975). Recirculation of leukocytes predominantly lymphocytes is essential for the function of immune sytem. The selectivity of the leuokocyte infiltration of tissue that occurs in some types of inflamation could be exerted by the stimulus for margination on the stimulus for a migration it is noted that selective margination of lymphocytes occurs in post-capillary venules of lymphoid tissues. Recently it is well documented that this complex process is mediated by certain adhesion molecules including selectins, intercellular adhesion molecules,integrins and their ligands (Shimizu et al., 1992). The migration of leukocytes into lymphoid organs and especially tissue is a multistep process initiating with the rolling of leukocytes on endothelium, than a firmer adhesion step allowing interaction of endothelial cells and leukocytes finally migration through vessel wall. We used zinc iodide-osmium tetroxide (ZIO) staining technique which distinguish endothelial cell clearly (Dag `deviren et al., 1994) aiming to obtain ultrastructural data on this unique relationship.

\section{MATERIAL AND METHOD}

In our study Ten adult wistar albino rats weighing 180-200 g were used to obtain tissue samples. The animals were sacrificed by decapitation under ether anesthesia. The lymph nodes of the animals were then quickly removed. Specimens were immersed in the zinc iodide-osmium tetroxide (ZIO) solution by Niebauer et al. (1969) and kept in the dark for 2 hours in this solution from temperature for fixation/staining. 
Samples were processed according to routine plastic embedding technique. Semithin sections of $1 \mu \mathrm{m}$ thick were cut and stained with methylene blue-azure II for light microscopic examination. Thin sections of 70nm thick were stained with lead citrate-uranyl acetate and examined and photographed under Zeiss EM-9S.

\section{RESULTS}

We observed many samples demonstrating the interactions between leukocytes, predominantly lymphocytes with endothelial cell and presented some. Margination and firm adhesion of lymphocytes to endothelial cells is distinguished from the rolling or temporary adhsesion by the presence of interdigitations on both cell and cross-binding of the leukocytes extending through the entire length of the lumen being attached to endothelial linings of opposite walls (Fig. 1). At higher magnifications interdigitations of fingerlike projections of lymphocytes are resolved better (Fig. 2). Migration of lymphocytes into the lymph nodes occur through high endothelial venules, specialized postcapillary venules with a tall endothelial lining. The blood vessels are easily distinguished by the presence of migrating lymphocytes in their walls (Fig. 3). Height of the endothelial lining is determined by the number of migrating lymphocytes in the wall. Endothelial lining becomes taller when a cell is migrating through it (Fig. 4). We observed the centrosome of migrating lymphocytes, whenever available on the section plane, always at the pole to which migration is directed (Fig. 5).

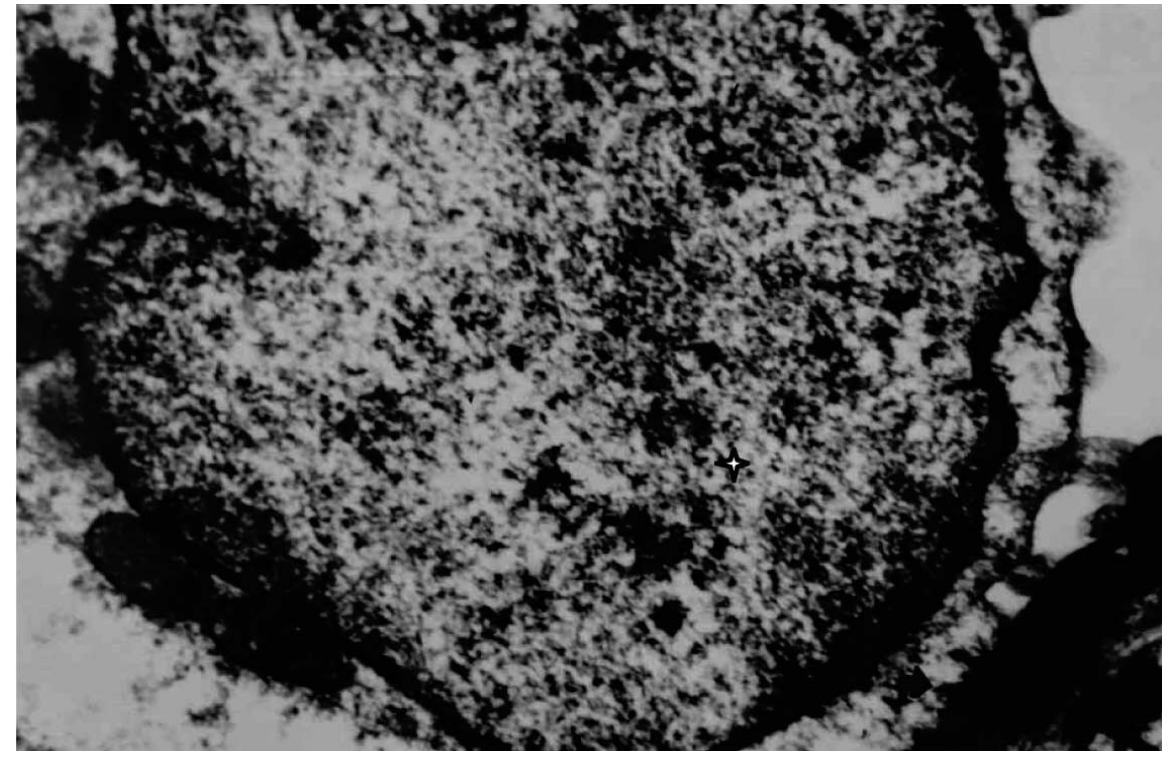

Fig. 1. A section through a post capillary venule stained with zinc iodide-osmium tetroxide tecnique. Endothelial cell are strongly ZIO (+). A lymphocyte $(*)$ is extending through and attached to the opposite wall of the vessel (Zinc iodide-osmium tetroxide, lead citrate-uranyl acetateX 6800).

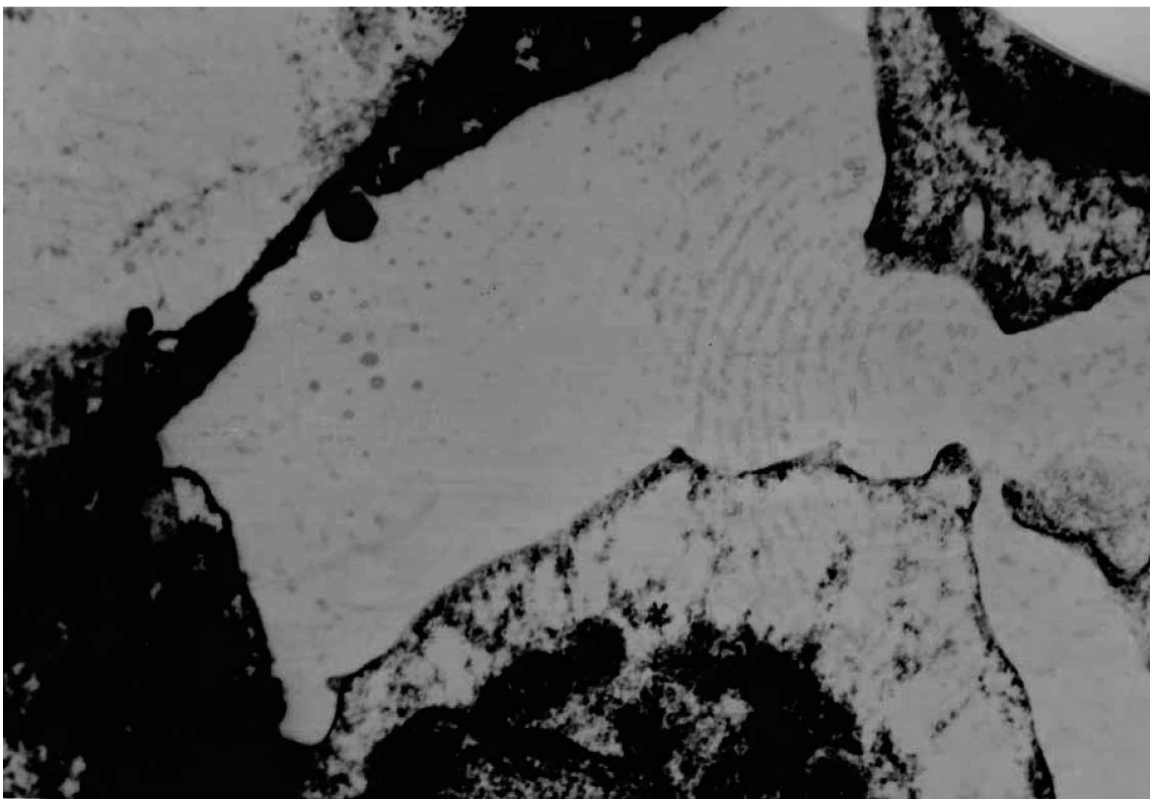

Fig. 2. Attachment of a lymphocytes to ZIO (+) Endothelium. Fingerlike projections of the lymphocyte interdigitate with the apical membrane of the endothelial cell (arrows). Collagen bundles $(\mathrm{CO})$ and A Cross section of a fibroblast process are seen in the underlying connective tissue (Zinc iodide-osmium tetroxide,lead citrate-uranyl acetateX 10600).

\section{DISCUSSION}

Leukocyte recruitment is essential for regulating immune functions and many inflammatory processes (Granger \& Kubes; Takahashi et al.,1994). To encompass the known phenomena a general theory of leukocyte margination and 


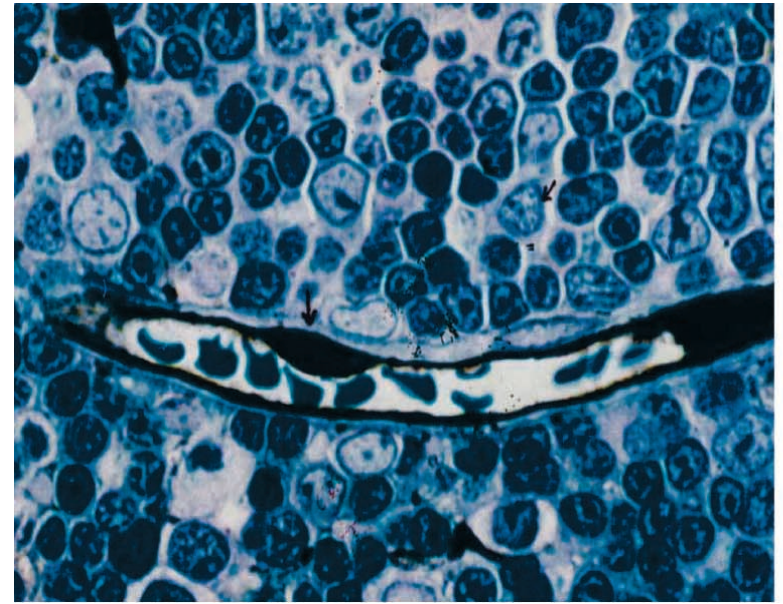

Fig. 3a. A capillary with ZIO technique at light microscopic level (Methlene blue-Azur II counterstained,original magnificationX40).

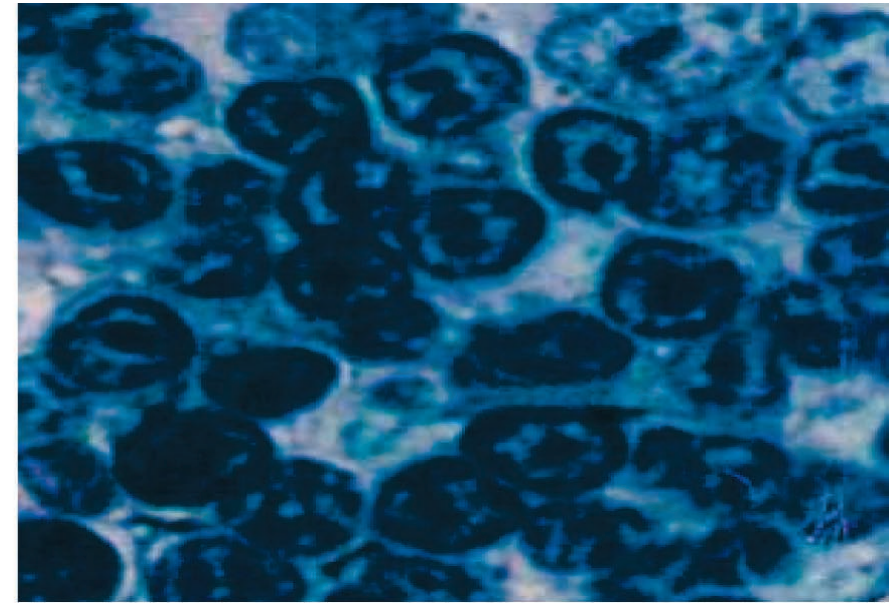

Fig. 3b. A high endotheial venule with migrating lymphocytes (arrows) in its tall endothelial wall (Methlene blue-Azur II counterstained, original magnificationX40).

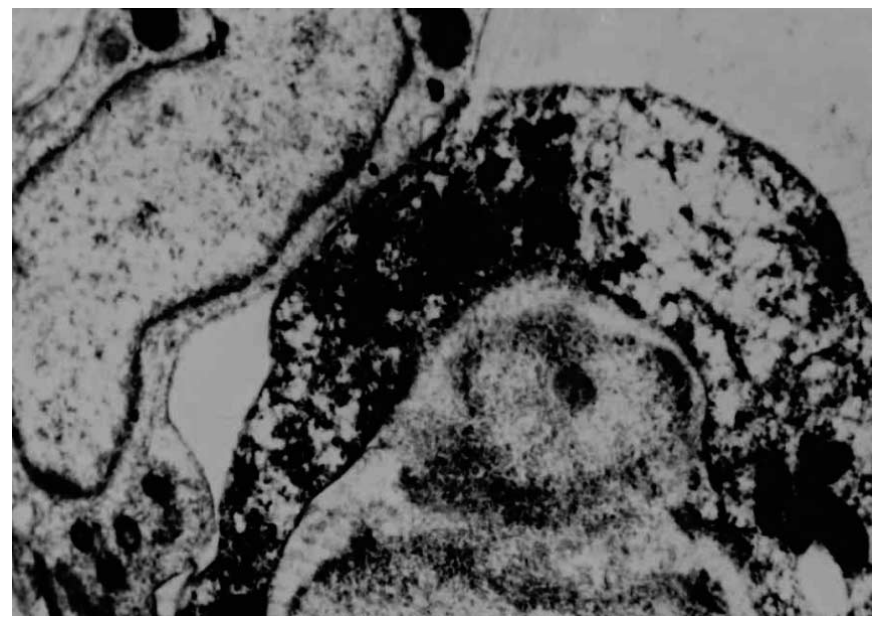

Fig. 4. A section through a post capillary venule. Endothelial cell through which a lymphocytes is migrating is densely ZIO (+) (Zinc iodideosmium tetroxide,lead citrate-uranyl acetateX 7400).

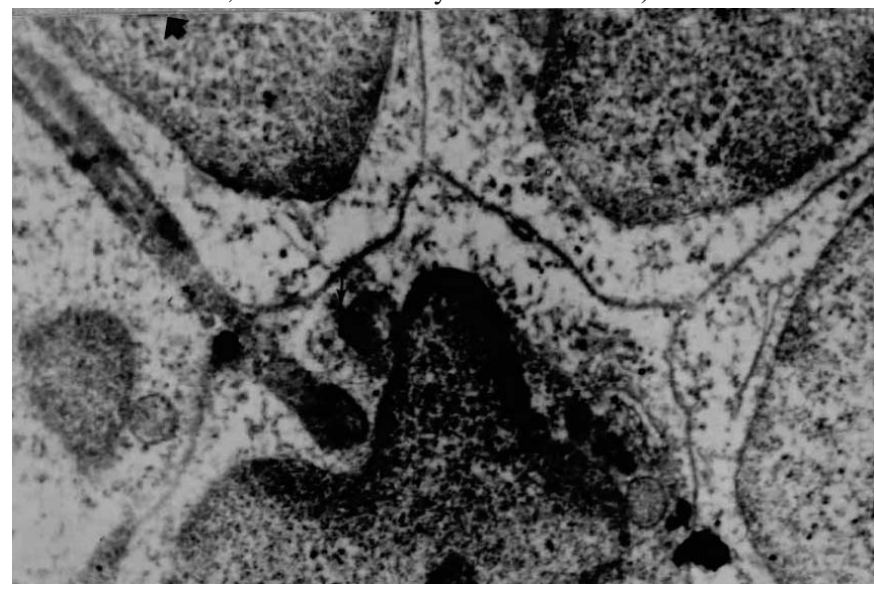

Fig. 5. A migrating leukocyte in the pericyte sheath of a high endothelial venule.Note the centriole pair (arraow). It is located at the pole to which the migrating is directed (Zinc iodide-osmium tetroxide, lead citrateuranyl acetateX 7300 . migration would predict that leukocytes selectively marginate on the acceptor molecules expressed by endothelium and extravasate in response to a chemotactic stimulus (Colditz, 1985). During lymphocyte recirculation high endothelial venules represent a primary site for lymphocyte migration to lymph nodes, tonsils mucosa associated lymphoid tissues and to connective tissues under inflammatory conditions (Dag deviren et al.). Farr \& De Bruyn reported that the migration of lymphocytes through post capillary venules occur via a transendothelial route relying on their examinations of serial sections of these vasculature. Though migration pat of lymphocytes through endothelium is still a matter of discussion either occuring through endothelial cells themselves or through intercellular juntions. We also observed that this migration occurs through the endothelial cells themselves not through the interendothelial junctions at least in many instances relying on our extensive examinations.Motility of the lymphocytes is provided by the sentriole pair and associated cytoskeletal elements. We observed sentrioles of migrating cells at their pole to which the migration of these cells is directed. This observation supports the role of sentriole in the migration process. Our ultrastructural observations also supports the functional molecular data reflecting the structural basis of this unique interaction (migration and margination) between endothelial cell and leukocytes. Combination of immunohistochemical and electron microscopic techniques will be the next step of our research which will provide us a more clear and certain evidence for the role of adhesion molecules in this process and fulfill the understanding of this complex phenomenon. 
DEVECI, E \& DEVECI, I. Evidencias ultraestructurales de las interacciones células endoteliales - leucocitos: marginación y migración. Int. J. Morphol., 28(3):895-898, 2010.

RESUMEN: Las interacciones entre células endoteliales y leucocitos tienen un papel fundamental en la respuesta inmune. Se utilizaron 10 ratas albinas Wistar, adultas, con peso entre 180-200 g, para obtener muestras de tejido. Los animales fueron sacrificados por decapitación bajo anestesia con éter. Inmediatamente, los nodos linfáticos de los animales fueron removidos. Las muestras se sumergieron en tetraóxido de osmio-yoduro de zinc (ZIO), solución de Niebauer et al. (1969), manteniéndose en oscuridad durante 2 horas, a temperatura de fijación/tinción. Las muestras fueron tratadas de cuerdo a la rutina de la técnica de inserción en plástico. Para el examen microscópico de luz, se tiñeron con Azur-II - Azul de metileno secciones de corte semifinos de 1 $\mu$ m de grosor. Se utilizó la técnica tinción tetraóxido de osmio-yoduro de zinc para distinguir las células endoteliales de los leucocitos. Los datos presentados apoyan la comprensión de esta relación única.

PALABRAS CLAVE: Leucocitos; Marginación; Migración.

\section{REFERENCES}

Colditz, I. G. Margination and emigration of leucocytes. Surv. Synth. Pathol. Res., 4(1):44-68, 1985.

Dag `deviren, A.; Alp, H. \& Ors, U. New applications for the zinc iodide-osmium tetroxide. J. Anat., 184:83-91, 1994.

Farr, A. G. \& De Bruyn, P. P. The mode of lymphocyte migration through postcapillary venule endothelium in lymph node. Am. J. Anat., 143(1):59-92, 1975.

Granger, D. N. \& Kubes, P. The microcirculation and inflammation: modulation of leukocyte-endothelial cell adhesion. J. Leukoc. Biol., 55(5):662-75, 1994.

Niebauer, G.; Krawczyk, W. S.; Kidd, R. L. \& Wilgram, G. F. Osmium zinc iodide reactive sites in the epidermal Langerhans cell. J. Cell Biol., 43(1):80-9, 1969.

Shimizu, Y.; Newman, W.; Tanaka, Y. \& Shaw, S. Lymphocyte interactions with endothelial cells. Immunol. Today, 13(3):106-12, 1992.

Takahashi, M.; Ikeda, U.; Masuyama, J.; Kitagawa, S.; Kasahara, T.; Saito, M.; Kano, S. \& Shimada, K. Involvement of adhesion molecules in human monocyte adhesion to and transmigration through endothelial cells in vitro. Atherosclerosis, 108(1):73-81, 1994.

\section{Corespondence to: \\ Engin Deveci \\ Dicle University \\ Medical Faculty \\ Histology and Embryology \\ Dept. 21280 Diyarbakır \\ TURKEY}

Tel: $9004122488001 / 4443$

Fax: 9004122488435

Email: engindeveci64@gmail.com

Received: 30-09-2009

Accepted: 12-03-2010 